\title{
EFL Learners' Perceptions Regarding the Use of Busuu Application in Language Learning: Evaluating the Technology Acceptance Model (TAM)
}

\author{
Mada AlDakhil ${ }^{1} \&$ Hind AlFadda $^{1}$ \\ ${ }^{1}$ College of Education, King Saud University, Riyadh, Kingdom of Saudi Arabia \\ Correspondence: Mada AlDakhil, College of Education, King Saud University, Riyadh, Kingdom of Saudi \\ Arabia.
}

Received: April 6, 2021

Accepted: December 6, 2021

Online Published: December 8, 2021

doi: $10.5539 /$ elt.v15n1p1

URL: https://doi.org/10.5539/elt.v15n1p1

\begin{abstract}
After the exceptional circumstances the whole world has experienced due to the COVID-19 pandemic, students have become digital natives who seek learning that overcomes the barriers of place and time. This mixed-methods study aimed at investigating EFL learners' perceptions regarding the application of Busuu in language learning, by applying the Technology Acceptance Model (TAM). The participants were 58 first secondary stage students in a Saudi private school. An online survey and a semi-structured interview were used to collect data. The results revealed that EFL learners have a positive attitude towards Mobile Assisted Language Learning (MALL).

Additionally, according to the TAM, the participants found the language application Busuu useful and easy to use. They also thought of Busuu as a valuable resource for language learning, which increases their motivation to be autonomous learners. However, in addition to the TAM components, the results also showed that affordance and joyfulness could be strong indicators of learners' acceptance of a particular technology.

Moreover, the results revealed that mobile applications might be more helpful for beginner learners than advanced ones. On the other hand, the findings also showed that Busuu might distract learners from doing their homework. Besides, the regular use of Busuu might be harmful to their eyes due to the small mobile screen size. For further research, the recommendation includes a large sample size in addition to a long-term study of EFL learners' perception towards Busuu in normal classroom circumstances.
\end{abstract}

Keywords: Busuu, EFL learners, MALL, Mobile Learning Applications, TAM

\section{Introduction}

Learning is a lifelong process and in our changing time, learners are more driven towards using their mobile phones for almost every purpose. As a result, it has been argued that traditional learning is no longer suitable for today's learners, which might create a massive gap between what students are learning in their classes and their everyday lives (Alshabeb \& Almaqrn, 2018). Nowadays, the world's learning systems have changed as a result of the COVID-19 pandemic. Most of the governments have established, based on technology, a distance educational systems for their citizens. Students are learning distantly at home, which influenced the selection of online educational resources planned for students and teachers (Reimers, Schleicher, Saavedra, \& Tuominen, 2020). Consequently, it might be said that integrating technology in general and mobile applications in specific into the learning process is crucial for both students and teachers.

Mobile-assisted language learning (MALL) has been commonly discussed topic in language education literature (Burston, 2014). As a result of the increasing interest in mobile learning (m-learning), researchers have investigated the purpose and factors that might influence m-learning's acceptance among students (Al-Emran, Mezhuyev, \& Kamaludin, 2018; Laurillard, 2007). Thus, the researchers adopted the Technology Acceptance Model (TAM). Venkatesh and Davis (1996) first developed the TAM, arguing that it has proven to be an accurate indicator of learners' acceptance (Venkatesh \& Davis, 2000).

Nowadays, language learning applications such as Busuu, Babbel, Duolingo, FluentU, Memrise, etc., offer EFL learners the opportunity to learn the language independently and in a personalized manner (Nushi \& Jenabzadeh, 
2016). To specify, Busuu is a language-learning mobile application designed to combine self-managed language learning with a supportive social network of language learners worldwide (Busuu, 2020).

All in all, the kingdom of Saudi Arabia is considered one of the countries with a high percentage of mobile phone users in the globe. However, there is only limited published researches investigating the adoption of m-learning among Saudi EFL learners (Seliaman \& Al-Turki, 2012). Nevertheless, the Saudi government has made substantial development in increasing the adoption of technology in education as one of the goals of the Saudi vision of the year 2030 (Rajab, 2018).

\subsection{Rationale and Research Questions}

For such significance of technology in general and MALL in specific, this research aims to investigate, through applying the TAM, Saudi EFL learners' perceptions towards learning the language via the application of Busuu. Moreover, it intends to highlight EFL learners' awareness of new methods of learning the language. Finally, to further research, this study can be used as a reflection on EFL learners' attitudes in the direction of learning the language through mobile applications.

The present research attempts to answer the following questions:

1) What are EFL learners' perceptions towards Mobile Assisted language learning MALL?

2) What are EFL learners' perceptions towards learning the language through Busuu?

3) Do learners think of Busuu as an easy learning tool?

4) Do learners think of Busuu as a useful learning tool?

5) Does the Busuu meet learners' expectations?

\section{Literature Review}

\subsection{Mobile Assisted Language Learning (MALL)}

Valarmathi (2011) defined MALL as a language learning approach that supports the use of a handheld mobile device, which is a division of mobile learning (m-learning) and Computer Assisted Language Learning (CALL) collectively. Kloper, Squire and Jenkins (2002) stated that m-learning provides learners with four properties: portability, social interactivity, context-sensitivity, and connectivity. Numerous researchers have reported EFL learners' positive attitudes towards MALL (Looi et al., 2010; Thornton \& Houser, 2005). However, it has been argued that MALL can have some drawbacks such as the limited presentation of graphics, restricted data storage, and most importantly, many mobile phones are not designed to support educational purposes (Albers \& Kim, 2001; Stockwell, 2008). Therefore, it might be challenging for learners to use them in this context.

Since language learning applications appeared, researchers have examined their impact on EFL learners' language proficiency and perception. Numerous research studies supported language learning applications in enhancing EFL learners' knowledge of the language, such as (Castaneda \& Cho, 2016; Kim, 2013; Rosell-Aguilar, 2016; Yildiz, 2012). However, a few argued that it could have its restrictions (Burston, 2014; Rosell-Aguilar, 2017).

Studies investigating language applications' effectiveness in Saudi literature and EFL learners' attitudes towards them are limited (Alabbad \& Huwamel, 2020; Bahjet Essa Ahmed, 2016). Although the Saudi literature is limited in investigating language learning apps, there are studies which investigated social media applications to foster foreign language learning, such as (Abdulaziz Al Fadda, 2020; Haque \& Al Salem, 2019).

\subsection{Technology Acceptance Model (TAM)}

Davis, in 1989, came up with the technology acceptance model (TAM), based on the Fishbein and Ajzen (1975) Theory of Reasoned Action (TRA) (Abdullah \& Ward, 2016). The TAM suggests that the main factors influencing an individual's attitude towards using technology are the usefulness and ease of using that technology (Davis, 1989). Perceived usefulness is defined as "the degree to which a person believes that using a particular system would enhance his or her job performance." while perceived ease of use indicates "the degree to which a person believes that using a particular system would be free of effort." (Davis, 1989: 320)

Altogether, the implementation of TAM in e-learning acceptance research has been approved by several researchers (Al-Emran et al., 2018; Althunibat, 2015). However, even though usefulness and ease of use are the key factors in accepting and using technology, according to TAM, several researchers have recognized other external factors that might play crucial roles in strengthening the TAM model. For instance, Moon and Kim (2001) stated that in addition to usefulness and ease of use, perceived playfulness could be a substantial factor in predicting learners' acceptance of the technology. Furthermore, in an empirical study, Ngai, Poon and Chan 
(2007) found out that the two components of TAM (usefulness and easiness of use) are radically influenced by the learners' satisfaction with technical support.

\subsection{Busuu in the Language Classroom}

The language application Busuu, which also offers a website, provides courses in 12 languages for more than 100 million registered learners worldwide. Learners can start learning for free or subscribe to a premium membership to unlock additional app features. In 2015, Busuu had a partnership with McGraw-Hill Education to offer users an official certificate to validate their learning. Furthermore, Busuu's lessons are classified according to the Common European Framework of Reference (CEFR). Thus, once learners finish a certain level and apply for the test at the end, they could receive their certificate if the test went successfully. The language courses in Busuu cover the four skills - listening, speaking, reading and writing. In addition to vocabulary, and translation. Also, it offers its users the ability to share and practice with native speakers (Busuu, 2020).

The available literature regarding the use of the application Busuu is limited. However, several of studies were conducted to investigate the effectiveness of Busuu in language learning and explore learners' attitudes towards it. In a pilot study using Busuu, Kétyi (2013) offered a free 7-days premium membership trial for 59 Hungarian students who learn German as a foreign language. The participants were asked to answer a survey questionnaire to report their opinions regarding Busuu. The result showed that $79 \%$ of the participants described Busuu as good or very good. However, some participants indicated that a few tasks were predictable and repetitive. Yet, After the free trial, most participants stated that they would not pay for the membership.

After that, in a follow-up experimental study, Ketyi (2015) compared 51 students using the premium version of Busuu with 43 students who did not use the app. The results disclosed that over $73 \%$ of the experimental group found the app useful. Moreover, the experimental group showed increased motivation and better target language performance compared to the control group. Despite that, participants showed no interest in paying for the premium membership after finishing the trial period (Kétyi, 2016). Furthermore, a study was conducted by Vesselinov and Grego (2016), who randomly chose a sample of 196 Busuu users. The participants studied Spanish with Busuu for two months. The results revealed that $84 \%$ of participants improved their knowledge of Spanish. They also explained that learning through Busuu was enjoyable.

Another study that reported the positive result of Busuu was the study conducted by Rosell-Aguilar (2018). This study surveyed 4095 users of Busuu learning a foreign language. The results revealed that most of the participants were at a beginner level. However, they stated that Busuu increased their knowledge of the language they were learning, especially vocabulary. Moreover, most of them considered language learning apps as reliable learning tools.

Recently, Citrayasa (2019) conducted a hermeneutic phenomenology study to investigate EFL learners' opinions regarding learning the language via Busuu. The study revealed that Busuu could be valuable in language learning; hence learners can learn anywhere. Also, the participants stated that Busuu had improved their learning autonomy.

Although the research on Busuu as a language app is limited, a few studies confirmed its usefulness as an online site. For instance, a study was conducted by Liu et al. (2013) to report EFL learners' perceptions regarding the social network site Busuu in language learning. The participants were 21 EFL learners who used Busuu outside their classroom for nearly 30 to 60 minutes. The result showed that the participants stated that Busuu is a valuable language learning tool. Also, they liked the fact that they were able to interact with other users on Busuu.

\section{Methodology}

\subsection{Research Design}

This study integrated both quantitative and qualitative methods using a mixed-methods sequential explanatory research design. According to Pardede (2019), mixed methods research provides the design with more prosperous and detailed findings, allowing the researcher to better understand a particular research problem.

\subsection{Setting and Participants}

The research was conducted in a private high school in Riyadh City. However, the study took place online due to the Covid-19 pandemic circumstances. This study's participants were the first secondary stage (10th grade) female students with an average age of 16 . They were 58 students who have a daily English online class in their schedule for 45 minutes. Unlike most Saudi public-school students who start learning English in grade 4, most of the study's participants have begun learning English from Grade 1 in private elementary schools. Besides, all participants are Arabic native speakers learning English as a foreign language. 


\subsection{Procedure}

The procedure for conducting this study was divided into five stages as shown in figure 1 .

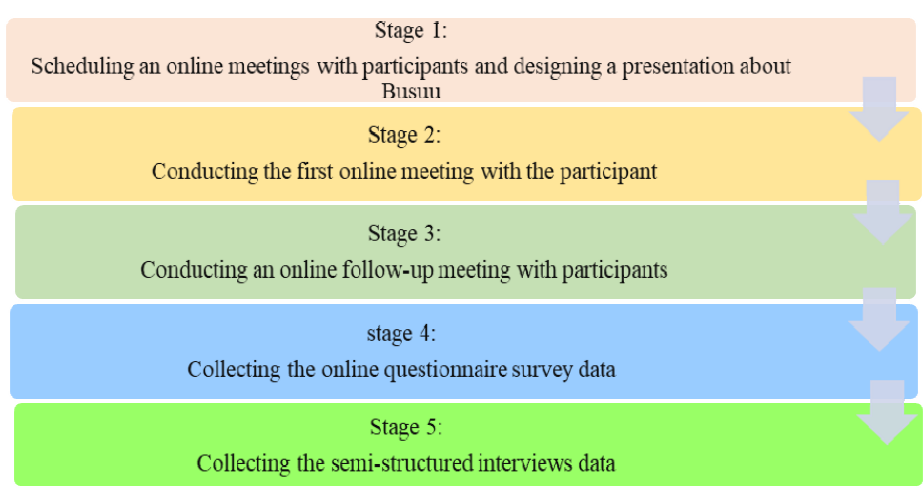

\subsection{Data Collection and Analysis}

Figure 1. The procedure followed by the researcher

Both an online questionnaire survey (Quantitative method) and a semi-structured interview (Qualitative method) were used to strengthen and enrich the study conclusions.

\subsubsection{Survey}

The first instrument used in this research to gather data was a structured online survey designed according to the Likert scale (1932) using Google forms website. The survey consisted of 33 multiple choice questions within four sections developed to answer the research questions (see Figure 2). After sending the survey to the participants, the collected responses were 44 out of 58 of the entire population. According to the scientific research standards, this percentage is considered representative of the whole population (Binu, Mayya, \& Dhar, 2014). To meet validity and accuracy, the survey was sent to the respondents with teaching experience to test its validity. On the other hand, the survey's reliability was verified using the Cronbach alpha, where the value of 0.894 was achieved, exceeding the Cronbach Alpha coefficient's acceptable percentage of 0.70. Finally, for data analysis, the researcher used the Statistical Package for Social Science (SPSS) version 25.

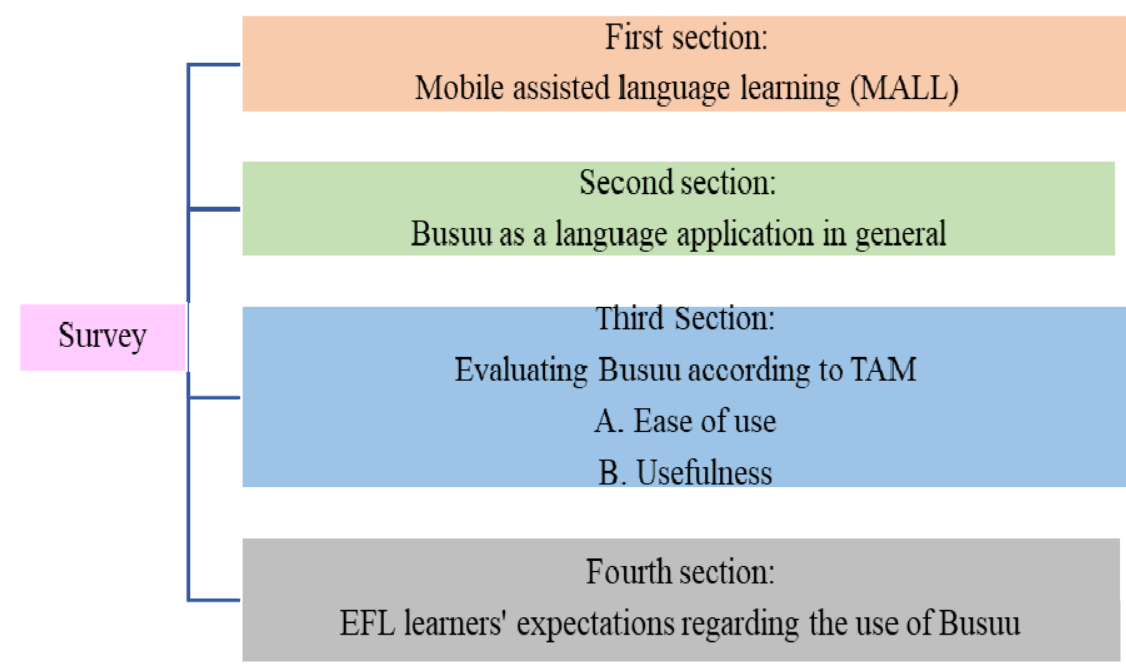

Figure 2. The four stages of developing the study's survey

\subsubsection{Semi-Structured Interview}

For the qualitative data gathered, the researcher used a semi-structured interview. However, six students only showed an interest in doing the semi-structured interviews. Yet only five girls were interviewed; the sixth one has decline to participate later.

In all interviews, the participants were asked five main questions as followed:

1) What do you think of Mobile-Assisted Language Learning (MALL)?

2) How was your experience of using Busuu? 
3) Do you think that Busuu has improved your academic performance in the classroom?

4) While using the app, did you face any difficulties?

5) Have you asked your parents for some money to unlock some items in the app?

The interview was held online using Zoom platform meetings application. After the data collection, interviews were transcribed and analyzed using thematic analysis (deductive approach).

\section{Findings}

A number of analyses were used in analyzing the survey and the semi-structured interview. The findings are presented as answers to the research questions which the current study sought to investigate.

\subsection{The Survey Data}

A five-point Likert scale was used to measure EFL learners' perceptions of Busuu. Levels of agreement or disagreement among participants were specified based on the criteria in table 1.

Table 1. Levels of agreement or disagreement

\begin{tabular}{ll}
\hline Mean range & Interpretations \\
\hline $3.40-5.00$ & High \\
$2.39-3.60$ & Moderate \\
$1.00-2.59$ & Low \\
\hline
\end{tabular}

\subsubsection{EFL Learners' Perception Towards MALL}

Table 2 reports the statistical analysis of EFL learners' perception towards MALL by the mean and standard deviation of each response.

Table 2. EFL learners' perceptions towards using Busuu in general

\begin{tabular}{|c|c|c|c|c|}
\hline \multicolumn{2}{|c|}{ Questions } & \multirow{2}{*}{$\begin{array}{l}\text { Mean } \\
4.25\end{array}$} & \multirow{2}{*}{$\begin{array}{l}\text { SD } \\
1.01\end{array}$} & \multirow{2}{*}{$\begin{array}{l}\text { Rank } \\
1\end{array}$} \\
\hline 1 & Mobile phones can be an effective tool for EFL learners. & & & \\
\hline 2 & Portability is an important aspect of mobile phones. & 4.13 & 1.03 & 2 \\
\hline 3 & Using mobile phones in language learning saves money. & 3.84 & 1.01 & 4 \\
\hline 4 & Using mobile phones in language learning saves time. & 3.88 & 1.14 & 3 \\
\hline 5 & Mobile phones can provide EFL learners with an interactive learning environment. & 3.77 & 0.96 & 5 \\
\hline 6 & Learning the language through a mobile application is new to me. & 3.02 & 1.22 & 6 \\
\hline \multicolumn{2}{|c|}{ Weighted mean } & \multicolumn{3}{|l|}{3.8030} \\
\hline \multicolumn{2}{|c|}{ St. Deviation } & \multicolumn{3}{|l|}{0.78817} \\
\hline
\end{tabular}

Table 2 shows that the highest rank was given to statement 1: (Mobile phones can be an effective tool for EFL learners.) with a mean of 4.25 and SD 1.01, followed by statement 2: (Portability is an important aspect of mobile phones.) with mean 4.13 and SD 1.03. While the lowest rank was awarded to statement 6: (Learning the language through a mobile application is new to me.) with a mean of 3.02 and SD 1.22, followed by statement 5: (Mobile phones can provide EFL learners with an interactive learning environment.) with mean 3.77 and SD 0.96. So, the average of EFL learners' perceptions towards MALL is (3.8030), which is according to the levels of agreement and disagreement showed in Table 1, consider a high level of acceptance towards MALL.

\subsubsection{EFL Learners' Perceptions Towards Learning the Language through Busuu}

Table 3 reports the statistical analysis of EFL learners' perceptions towards Busuu by the mean and standard deviation of each response. 
Table 3. EFL learners' perceptions towards using Busuu in general

\begin{tabular}{lllll}
\hline Questions & Mean & SD & Rank \\
\hline 7 & I use Busuu once to several times a day. & 3.22 & 1.13 & 6 \\
8 & I use the application Busuu once to twice a week. & 3.36 & 1.22 & 5 \\
9 & I spend from 5 to 10 minutes using Busuu. & 3.70 & 1.19 & 4 \\
10 & I spend more than 10 minutes using Busuu & 3.72 & 1.18 & 3 \\
$\quad$ I like all the features in the application Busuu (Grammar practice, vocabulary & & & \\
$11 \quad$ practice, reading practice, writing practice, listening practice, and sharing feedback & 4.18 & 0.81 & 2 \\
$\quad$ with different users). & & & \\
12 & I think that the automated feedback in Busuu is excellent (when your answer turns \\
$\quad$ green if correct or red when you make an error). & 4.52 & 0.62 & 1 \\
13 & I share my writing exercise with Busuu users. & 3.13 & 1.26 & 7 \\
14 & I provide correcting/ feedback for other Busuu users & 2.88 & 1.38 & 8
\end{tabular}

As shown in Table 3, the highest rank was awarded to statement 12: (I think that the automated feedback in Busuu is excellent (when your answer turns green if correct or red when you make an error.) with a mean 4.52 and SD 0.62, followed by statement 11: (I like all the features in the application Busuu (Grammar practice, vocabulary practice, reading practice, writing practice, listening practice, and the ability to share feedback with different users.)) with mean 4.18 and SD 0.81. While the lowest rank was awarded to statement 14: (I provide correcting/ feedback for other Busuu users.) with a mean of 2.88 and SD 1.38, followed by statement 13: (I share my writing exercise with Busuu users.) with mean 3.13 and SD 1.26.

Thus, it might be said that the average of EFL learners' perceptions of Busuu is (3.5938), which indicates a high level of satisfaction among participants. Thus, according to the agreement and disagreement levels shown in table 1 , the participants shown high levels of interest in using Busuu to learn the language.

\subsubsection{Busuu as an Easy Learning Tool}

Table 4 contains six items that represent EFL learners' attitudes towards Busuu as an easy learning tool by the mean and standard deviation of each response.

Table 4. EFL learners' perceptions towards Busuu as an easy learning tool

\begin{tabular}{|c|c|c|c|}
\hline Questions & Mean & SD & Rank \\
\hline 15 Registering to Busuu was easy. & 4.52 & 0.50 & 2 \\
\hline 16 The using instructions in Busuu were clear. & 4.52 & 0.69 & 2 \\
\hline 17 I find Busuu simple in design and easy to navigate. & 4.56 & 0.54 & 1 \\
\hline 18 I can manage my account and switch between lessons smoothly. & 4.31 & 0.70 & 3 \\
\hline $\begin{array}{l}19 \text { I think of Busuu as an accessible resource when I struggle with a particular topic in } \\
\text { class. }\end{array}$ & 3.68 & 1.00 & 4 \\
\hline 20 I enjoyed learning the language using Busuu. & 4.31 & 0.73 & 3 \\
\hline $\begin{array}{l}\text { Weighted mean } \\
\text { St. Deviation }\end{array}$ & $\begin{array}{l}4.3220 \\
0.4692\end{array}$ & & \\
\hline
\end{tabular}

Based on Table 4, the highest rank was given to statement 17: (I find Busuu simple in design and easy to navigate) with mean 4.56 and SD 0.54, followed by statement 15: (Registering to Busuu was easy), and 16: (The using instructions in Busuu were clear), with the same mean average 4.52 and SD 0.50, 0.69, respectively. While the lowest rank was found in statement 19: (I think of Busuu as an accessible resource when I struggle with a particular topic in class) with a mean of 3.68 and SD 1.00 which is considered a high agreement with the ease of use of Busuu.

The weighted mean average of section one was 4.3220 with SD 0.46920 , which indicates a high level of satisfaction among participants. According to the levels of agreement and disagreement shown in table 1, the 
study's participants have shown a high level of acceptance towards Busuu as an easy language learning application.

\subsubsection{Busuu as a Useful Learning Tool}

Table 5 contains seven items representing EFL learners' perceptions towards Busuu as a useful learning tool by the mean and standard deviation of each response.

Table 5. EFL learners' perceptions towards Busuu as a useful language tool

\begin{tabular}{lllll}
\hline Questions & Mean & SD & Rank \\
\hline 21 & Busuu has improved my overall knowledge of the language. & 4.02 & 0.73 & 3 \\
22 & Busuu has motivated me to learn more about the language. & 4.01 & 0.94 & 4 \\
23 & Busuu has increased my responsibility for my own learning. & 4.25 & 0.71 & 2 \\
24 & Busuu has improved my academic performance in the classroom. & 3.84 & 0.77 & 6 \\
25 & Busuu has given me the courage to participate with my teacher in class. & 3.70 & 0.97 & 7 \\
26 & Busuu has given me a chance to design a learning plan that suits my needs. & 3.93 & 0.78 & 5 \\
27 & I think of Busuu as a helpful learning tool. & 4.45 & 0.54 & 1 \\
& $\quad$ Weighted mean & & 4.0455 & \\
St. Deviation & & 0.57538 & \\
\hline
\end{tabular}

Table 5 shows the highest rank was awarded to statement 27: (I think of Busuu as a helpful learning tool) with a mean of 4.45 and SD 0.54, followed by statement 23: (Busuu has increased my responsibility for my own learning) with mean 4.25 and SD 0.71, followed by statement 21: (Busuu has improved my overall knowledge of the language) with mean 4.02 and SD 0.73. While the lowest rank was awarded to statement 25: (Busuu has given me the courage to participate with my teacher in class.) with a mean of 3.70 and SD 0.97 , followed by statement 24: (Busuu has improved my academic performance in the classroom.) with mean 3.84 and SD 0.77.

Thus, the average of EFL learners' perceptions towards MALL is (3.8182). According to the levels of agreement and disagreement shown in table 1, participants are highly satisfied with Busuu as a useful language learning tool.

\subsubsection{EFL Learners' Expectations Regarding Busuu}

Table 6 reports the statistical analysis of EFL learners' expectations towards Busuu by the percentage of response for each possible answer along with the mean and standard deviation of each response.

Table 6. EFL learners' expectations regarding Busuu

\begin{tabular}{|c|c|c|c|c|}
\hline \multicolumn{2}{|c|}{ Questions } & \multirow{2}{*}{$\begin{array}{l}\text { Mean } \\
3.50\end{array}$} & \multirow{2}{*}{$\begin{array}{l}\text { SD } \\
1.21\end{array}$} & \multirow{2}{*}{$\begin{array}{l}\text { Rank } \\
5\end{array}$} \\
\hline 28 & Busuu was as I expected when I downloaded it. & & & \\
\hline 29 & I want to see more from Busuu, so I downloaded the premium membership. & 3.36 & 1.41 & 6 \\
\hline 30 & $\begin{array}{l}\text { I have a plan of getting my MGH English language certificate after finishing } \\
\text { my current level. }\end{array}$ & 3.93 & 1.06 & 3 \\
\hline 31 & I consider using Busuu to learn other languages in the future. & 4.36 & 0.74 & 2 \\
\hline 32 & Busuu has encouraged me to download other language apps. & 3.86 & 1.04 & 4 \\
\hline 33 & Busuu has increased my interest in learning the language. & 4.45 & 0.72 & 1 \\
\hline & $\begin{array}{l}\text { Weighted mean } \\
\text { viation }\end{array}$ & & $\begin{array}{l}3.912 \\
0.523\end{array}$ & \\
\hline
\end{tabular}

Table 6 shows the highest rank was awarded to statement 33: (Busuu has increased my interest in learning the language) with a mean of 4.45 and SD 0.72, followed by statement 31: (I consider using Busuu to learn other languages in the future) with mean 4.36 and SD 0.74 , followed by statement 30 : (I have a plan of getting my MGH English language certificate after finishing my current level) with mean 3.93 and SD 1.06. While the lowest rank was awarded to statement 29: (I want to see more from Busuu, so I downloaded the premium membership) with a mean of 3.36 and SD 1.41 . 
So, the average of EFL learners' perceptions towards MALL is (3.8182), which shows a high level of interest regarding using Busuu among the participants. Finally, table 7 represents the highest and the lowest rating among the four sections of the survey.

Table 7. The highest and lowest rating among the survey sections

\begin{tabular}{llll}
\hline Section number & Suction title & Mean & Rank \\
\hline 1 & EFL learners' perceptions towards MALL & 3.80 & 4 \\
2 & EFL learners' perceptions towards Busuu in general & 3.59 & 5 \\
$3 . A$ & EFL learners' perceptions towards Busuu as an easy learning tool & 4.32 & 1 \\
$3 . B$ & EFL learners' perceptions towards Busuu as a useful learning tool & 4.04 & 2 \\
4 & EFL learner' expectations regarding Busuu & 3.91 & 3 \\
\hline
\end{tabular}

As it can be seen in Table 7, the descriptive analysis showed that among all sections of the survey, Busuu's ease of use had the highest rating (mean=4.32), followed by Busuu's usefulness (mean=4.04), followed by future expectations about Busuu (mean=3.91), followed by MALL as an effective learning tool (mean=3.81). In contrast, Busuu, in general (mean=3.59), had the lowest rating.

\subsection{The Semi-Structured Interview Data}

The researcher thematically analyzed the data collected from the interviews to answer the research questions as follows:

\subsubsection{EFL Learners' Perceptions Towards MALL}

The interview findings showed the participants' positive attitudes towards MALL. They indicated an optimistic attitude towards the idea of integrating mobile phones into the language learning classroom. The main benefits of MALL, according to the participants, was accessibility, portability, and time-saving.

"I like learning using the phone. I take my phone everywhere I go, so I can learn anytime." [Participant B]

"....It saves time. When I am at home, I can study anytime. It made a lot of things easier." [ Participant C]

According to the participants, they spend a lot of time using their phones, which makes the idea of integrating them into their classroom very appealing. Thereupon, when they were asked about their preferences regarding learning in a traditional classroom-only or a classroom that merged mobile phones along with conventional learning, they all preferred the latter.

"I would defiantly choose the class which uses phone, because I can go back to the lessons whenever I want, unlike traditional classroom." [Participant A]

"Sure, Because I will be able to learn new information and not depend on the schoolbook only. "[ Participant c]

"of course, together because it is going to be easier". [Participant $\mathrm{d}$ ]

"In the blended, of course.... we are in a decade that technology is an important part of our life.... so I think it's very great instead of the boring traditional way .. we can actually use the technology in a good way. "[Participant E]

However, some of the participants conveyed their concerns regarding using mobile phones for learning purposes. For example, they indicated that it might be challenging to utilize, harmful to their eyes, time-consuming, and distract them from studying.

"I think it takes time, and at the same time, I like it. ......As for eyes, I think it is harmful." [participant A]

"To be honest, it might be a bit difficult, but at the same time, it is very beneficial.... I believe that it is bad for my eyes." [participant $\mathrm{C}$ ]

"At first it was hard for me because I get distracted easily." [participant D]

\subsubsection{EFL Learners' Perceptions towards Learning the Language through Busuu}

The results showed that all participants expressed their satisfaction when using Busuu. They believe that learning the language through Busuu was joyous. 
"honestly, it was so much fun. I see that it is enjoyable more than beneficial it was like playing a game ...." [participant $\mathrm{C}$ ]

"I loved it." [participant D]

"It's really great." [participant E]

Not only that, but one of the participants also shared her audio recordings with the Busuu community. When she was asked if she spoke more freely than she does in the classroom, she agreed. She also explained that she was relieved since she did not have to talk in front of everyone, like what usually happens in the classroom.

"I can listen to myself self and it is only in front of one person, unlike the classroom in front of everybody." [participant A]

4.2.3 EFL Learners' Perceptions Towards Busuu as an Easy Learning Tool

When the interviewees were asked if they find the Busuu easy to use, they all reported positively.

"I contacted them; they reply very fast." [Patrticipant A]

"I can go back to the lessons whenever I want." [participant B]

"The questions were clear and to the point." [participant $\mathrm{C}$ ]

To clarify, the researcher asked the participants if they faced any difficulties while using the app. However, answers agreed that no problems to mention, but one student complained about the paid premiership.

"Umm, nothing except the money since I don't have a lot of money." [participant E]

4.2.4 EFL Learners' Perceptions Towards Busuu as a Useful Learning Tool

One of the main questions the participants were asked was determining if they find Busuu a useful learning tool. Answers showed that most of the participants believed that Busuu helped them overcome obstacles in the classroom.

"If I don't understand something in class, I go and search for the lessons in Busuu." [participant D]

"I felt that it had improved my performance in the classroom." [participant A]

Yet, one of the interviewed participants believed that Busuu was not that much of a help for her. She explained that her language level was advanced already, and she was not sure of Busuu's usefulness to her.

"My English has always been like this." [participant E]

Moreover, when participants were asked if Busuu has increased their learning autonomy, they respond positively. Also, according to the participant, Busuu can help shy students get more self-confidence to share their ideas in the classroom. One of the participants revealed that she is a shy student who usually struggles to speak in class, and Busuu has helped her a lot in coming over this issue.

"Students might participate and speak more, because they can listen to their recording in Busuu, and if they feel that they can speak well, it will encourage them to speak in class." [participant C]

"I am a shy student, and Busuu helped me a lot." [participant D]

Another finding was regarding students' preferences to learn the language. Participants were asked if they prefer learning the language through applications such as Busuu or going to language learning centers. According to the participants and from their experience using Busuu, they believed that Busuu is better and more beneficial since they will have the chance to be responsible for their own learning.

"I have registered in those institutions once. I don't feel that it was beneficial to me. Using phone is better." [participant A]

"well, I believe if someone wants to the language, he should learn by himself.... For example, opens a language application instead of going to language learning centers, for example, which I believe a waste of time..... myself last year I had a language course in a language center which was not of that much benefit." [participant B]

However, the interviews' findings reported that one of the participants was not sure about the usefulness of Busuu because she didn't spend much time using the app since they were going through midterm exams periods.

"I didn't use it that much, to be honest, but I believe if I did, it would improve my performance ..... Well, I was studying for the test, and I had a lot of homework to do, so most of my time I was spending studying." [participant B] 
The researcher asked participants if the one-month experience of using Busuu was enough to determine its usefulness. The findings revealed that participants agreed that a one-month trial was enough to judge Busuu's effectiveness. However, some indicated that if they have been given the application Busuu on vacation, it would be more helpful because they will have more time to spend using the app.

"Umm, yeah, maybe if I took it for a quite long time, I can really learn." [participant $\mathrm{E}$ ]

\subsubsection{EFL Learners' Future Expectations Regarding Busuu}

The last interview question aimed to investigate participants' plans regarding the use of Busuu. One of the participants has reported that she already subscribed to the premium membership. However, most of the rest express their intentions to do so.

\section{"I subscribed for a year." [Participant A]}

"I intend to so soon." [Participant B]

"Yes, since it will help you studying." [Participant C]

"maybe in the future." [Participant D]

However, one of the participants expressed some doubts regarding subscribing to use Busuu in the future.

"I have actually thought about it ... but I was not quite sure since... I don't use things for a long term... I get bored really easily." [participant $\mathrm{E}$ ]

Despite that, the interviews revealed that participants showed a high interest in using the app in the future.

"I subscribed to the premium membership for a year because I tried it for a week, and it was very helpful." [participant A]

\section{Discussion}

Data analysis results that MALL can be an effective learning tool that provides learners with portability, save their time and money. Also, it equips learners with an interactive learning environment. This can be interpreted from their responses to the survey and answers to the interview questions. These conclusions supported the findings of Thornton and Houser (2005). Moreover, it is similar to Looi et al. (2010) findings. Parallel findings were mentioned by Kloper, Squire, and Jenkins (2002).

On the contrary, some participants have expressed their concerns regarding the use of MALL. This can be seen in the interview data where they stated that mobile phones could be an expensive learning tool. Not only that, but they mentioned that it could be harmful to their eyes and distract them from doing their homework. Those concerns might affect the participants' intention to accept MALL. These findings can be seen in Stockwell (2008) where participants indicated their worries about the cost of internet access and the small screen's harmful impact on their eyes.

Moreover, one of this study's conclusions is the optimistic attitude learners' have towards using Busuu in general. Quantitative and qualitative data showed that EFL learners were highly satisfied with the immediate automated feedback that Busuu offers. Also, they mentioned that they used Busuu regularly in their free time because they liked all the features that Busuu offers. In addition to that, they expressed their admiration for the ability to share their writing and speaking recordings. However, most of them shared neither their voice records nor their written texts yet. This is equivalent to the findings of Liu et al. (2013) and Looi et al. (2010).

Besides, this study findings revealed that according to TAM, Busuu is considered an easy and useful learning tool. (Busuu as an easy learning tool) the subsection in the survey got the highest percentage of agreement among the participants with a mean (4.32). According to the TAM, this indicates a high acceptance of Busuu among students. This conclusion can be evident also in the interview results, where all participants used the word "easy" to describe Busuu. There were no studies in the current literature that relate Busuu with the TAM model. However, other studies that investigated Busuu among users reported a high level of satisfaction among participants when it comes to Busuu as an easy learning tool such as Kétyi (2013) and Vesselinov (2016).

On the other hand, the current study reported a high acceptance of Busuu as a useful learning tool among participants since the subsection (Busuu as a useful learning tool) in the survey has the mean of (4.04), which is the second-highest section mean after (Buauu as an easy learning tool). Participants stated that Busuu was useful in increasing their overall knowledge of the language, assisting them in designing a learning plan that suits their needs, and motivating them to be autonomous language learners. As mentioned above, none of the studies that investigated Busuu related its findings with TAM. However, several studies supported the usefulness of Busuu as a learning tool. These results can be seen in the work of Rosell-Aguilar (2018) as well as Vesselinov and Grego 
(2016). Furthermore, these findings agree with Citrayasa (2019) results, where the participants indicated that Busuu improved their English skills and helped them focus more.

Nevertheless, the study findings revealed that in addition to the two components of TAM (ease of use and usefulness), other external factors such as joyfulness and affordability of the application could be strong indicators of learners' acceptance of that specific technology. These findings contribute to studies that use TAM in measuring students' acceptance of technology, such as Moon and Kim (2001) and Ngai, Poon and Chan (2007) who declared that TAM could be affected by Playfulness and technical support.

Another finding of this study suggests that Busuu can be more helpful among beginner learners than advanced ones. The same finding was discussed in Rosell-Aguilar (2018) work, where most of the participants who choose to practice using Busuu were beginners. Also, it supports the claim of Vesselinov and Grego (2016) who stated that apps usually attract beginner learners.

Furthermore, the findings revealed that Busuu have met most of the participants' expectations. Thus, most of them reported their intentions to download the premium membership and verify their learning by getting the MGH certificate. Those findings can be seen in the work of Law (2016). However, those findings oppose Kétyi (2013) and Kétyi (2016) where participants did not show any interest in paying for the premium membership.

Finally, most of the participants have considered Busuu to learn other languages and revealed a very positive attitude towards the use of Busuu in the future witch gives an idea that the participants in this study view Busuu as a valuable and reliable language learning source.

\section{Conclusions}

The current study attempted to explore EFL learners' perceptions of the language application Busuu applying TAM. The results suggested that MALL can increase EFL learners' autonomy and provide them with available valuable resources to learn the language anytime and anywhere. The findings also revealed that, according to EFL learners, Busuu is an easy and useful learning tool that they intend to use in their learning journey. However, the study showed that language applications might be more helpful for beginner EFL learners.

The results also revealed that there might be drawbacks to using mobile language learning applications, such as the small screen. Moreover, mobile applications can distract some learners since they may not resist switching between apps on their phones. Besides, the result of this study suggested that in addition to ease of use and usefulness (TAM components), affordability and joyfulness might affect EFL learners' acceptance of a particular technology.

Finally, due to the research questions and setting nature, certain limitations were considered in conducting this research. This study would provide a more precise result if the sample size were larger, including all secondary stages students from more than one school. Also, due to Covid-19 and distance learning circumstances, the participants were distracted by the new learning conditions they have to adapt themselves too quickly. Moreover, participants have reported their perceptions after a one-month trial only of the application. This period might be short for EFL learners to have a clear idea about the app and reflect on their experience.

\section{References}

Abdulaziz Al Fadda, H. (2020). Determining How Social Media Affects Learning English: An Investigation of Mobile Applications Instagram and Snap Chat in TESOL Classroom. Arab World English Journal (AWEJ), 11(1), 3-11. https://doi.org/10.24093/awej/vol11nol.1

Abdullah, F., \& Ward, R. (2016). Developing a General Extended Technology Acceptance Model for E-Learning (GETAMEL) by analysing commonly used external factors. Computers in Human Behavior, 56, 238-256. https://doi.org/10.1016/j.chb.2015.11.036

Alabbad, A. M., \& Huwamel, H. S. B. (2020). The Effect of Using Padlet as a Vocabulary Knowledge Enhancement Application on Saudi EFL Female Learners, and their Attitudes toward its Value in Learning. Arab World English Journal (AWEJ) Special Issue on CALL, (6), 357-378. https://doi.org/10.24093/awej/call6.24

Albers, M. J., \& Kim, L. (2001, October). Web design issues when searching for information in a small screen display. In Proceedings of the 19th annual international conference on Computer documentation (pp. 193-200).

Al-Emran, M., Mezhuyev, V., \& Kamaludin, A. (2018). Technology Acceptance Model in M-learning context: A systematic review. Computers \& Education, 125, 389-412. https://doi.org/10.1016/j.compedu.2018.06.008 
Alshabeb, A., \& Almaqrn, R. (2018). A study of EFL Saudi students' use of mobile social media applications for learning. Arab World English Journal (AWEJ) Special Issue on CALL, (4), 214-226. https://doi.org/10.24093/awej/call4.17

Althunibat, A. (2015). Determining the factors influencing students' intention to use m-learning in Jordan higher education. Computers in Human Behavior, 52, 65-71. https://doi.org/10.2139/ssrn.2814822

Bahjet Essa Ahmed, H. (2016). Duolingo as a bilingual learning app: a case study. Arab World English Journal (AWEJ), 7, 255-267.

Binu, V. S., Mayya, S. S., \& Dhar, M. (2014). Some basic aspects of statistical methods and sample size determination in health science research. Ayu, 35(2), 119. https://doi.org/10.4103/0974-8520.146202

Burston, J. (2014). The reality of MALL: Still on the fringes. Calico Journal, 31(1), 103-125. https://doi.org/10.11139/cj.31.1.103-125

Castaneda, D. A., \& Cho, M. H. (2016). Use of a game-like application on a mobile device to improve accuracy in conjugating Spanish verbs. Computer Assisted Language Learning, 29(7), 1195-1204. https://doi.org/10.1080/09588221.2016.1197950

Citrayasa, V. (2019). Junior high school students' lived experiences of learning English using Busuu. Indonesian EFL Journal, 5(2), 85-92. https://doi.org/10.25134/ieflj.v5i2.1900

Davis, F. D. (1989). Perceived usefulness, perceived ease of use, and user acceptance of information technology. MIS quarterly, 319-340. https://doi.org/10.2307/249008

Haque, S. F., \& Al Salem, N. M. (2019). Social Media in EFL Context: Attitudes of Saudi Learners. Journal of Language Teaching and Research, 10(5), 1029-1040. https://doi.org/10.17507/jltr.1005.16

Ibrahim, S., \& Ismail, F. (2021). University ESL Instructors' Reflections on the Use of Blended Learning in their Classrooms. TESOL and Technology Studies, 2(1), 25-35. https://doi.org/10.48185/tts.v2i1.117

Kétyi, A. (2013, September). Using Smart Phones in language learning-A pilot study to turn CALL into MALL. In Bradley, Linda \& Thouësny, Sylvie (Eds.), 20 Years of EUROCALL: Learning from the Past, Looking to the Future (pp. 129-134). https://doi.org/10.14705/rpnet.2013.000150

Kétyi, A. (2016). From mobile language learning to gamification: an overlook of research results with business management students over a five-year period. Porta Linguarum: revista internacional de didáctica de las lenguas extranjeras, (1), 45-59. https://doi.org/10.30827/Digibug.54087

Kim, H. S. (2013). Emerging mobile apps to improve English listening skills. Multimedia-Assisted Language Learning, 16(2), 11-30. https://doi.org/10.15702/mall.2013.16.2.11

Kloper, E., Squire, K., \& Jenkins, H. (2002, August). Environmental detectives: PDAs as a window into a virtual simulated world. In Proceedings IEEE International Workshop on Wireless and Mobile Technologies in Education (pp. 95-98). IEEE.

Laurillard, D. (2007). Pedagogical forms of mobile learning: framing research questions.

Law, P. (2016). The Identified Informal Learner: Recognizing Assessed Learning in the Open. In Bliss, T. J. \& Blessinger, Patrick (Eds.), Open Education: International Perspectives in Higher Education (pp. 137-158). https://doi.org/10.11647/OBP.0103.07

Likert, R. (1932). A technique for the measurement of attitudes. Archives of psychology.

Liu, M., Evans, M. K., Horwitz, E., Lee, S., McCrory, M., Park, J. B., \& Parrish, C. M. (2013). A study of the use of social network sites for language learning by university ESL students. In Lamy M. N., \& Zourou, K. (Eds.), Social networking for language education (pp. 137-157). Palgrave Macmillan, London. https://doi.org/10.1057/9781137023384_8

Looi, C. K., Seow, P., Zhang, B., So, H. J., Chen, W., \& Wong, L. H. (2010). Leveraging mobile technology for sustainable seamless learning: a research agenda. British journal of educational technology, 41(2), 154-169. https://doi.org/10.1111/j.1467-8535.2008.00912.x

Moon, J. W., \& Kim, Y. G. (2001). Extending the TAM for a World-Wide-Web context. Information \& management, 38(4), 217-230. https://doi.org/10.1016/S0378-7206(00)00061-6

Ngai, E. W., Poon, J. K. L., \& Chan, Y. H. (2007). Empirical examination of the adoption of WebCT using TAM. Computers \& education, 48(2), 250-267. https://doi.org/10.1016/j.compedu.2004.11.007 
Nushi, M., \& Jenabzadeh, H. (2016). Busuu: The mobile app. The TESL Reporter, 49(2), 30-38.

Pardede, P. (2019). Mixed Methods Research Designs in EFL. In PROCEEDING English Education Department Collegiate Forum (EED CF) 2015-2018. UKI Press, Indonesia, Jakarta, 230-243. Retrieved from https://repository.uki.ac.id/id/eprint/933

Rajab, K. D. (2018). The effectiveness and potential of E-learning in war zones: An empirical comparison of face-to-face and online education in Saudi Arabia. IEEE Access, 6, 6783-6794. https://doi.org/10.1109/ACCESS.2018.2800164

Reimers, F., Schleicher, A., Saavedra, J., \& Tuominen, S. (2020). Supporting the continuation of teaching and learning during the COVID-19 Pandemic.

Rosell-Aguilar, F. (2016). User evaluation of language learning mobile applications: a case study with learners of Spanish. In Palalas, Agnieszka \& Ally, Mohamed (Eds.), The International Handbook of Mobile-Assisted Language Learning (pp. 454-581). Beijing: China Central Radio \& TV University Press.

Rosell-Aguilar, F. (2017). State of the app: A taxonomy and framework for evaluating language learning mobile applications. CALICO journal, 34(2), 243-258. https://doi.org/10.1558/cj.27623

Rosell-Aguilar, F. (2018). Autonomous language learning through a mobile application: a user evaluation of the busuu app. Computer Assisted Language Learning, 31(8), 854-881. https://doi.org/10.1080/09588221.2018.1456465

Salayo, J., Fesalbon, J. E. R., Valerio, L. C., \& Litao, R. A. (2020). Senior high school teachers' and students' engagements during the emergency remote teaching (ERT): Perceptions on readiness, attitude, and competence. Studies in Humanities and Education, 1(1). https://doi.org/10.48185/she.v1i1.145

Seliaman, M. E., \& Al-Turki, M. S. (2012). Mobile learning adoption in Saudi Arabia. World Academy of Science, Engineering and Technology, 69(9), 391-293.

Start learning languages with Busuu today! - Busuu. (2020). Retrieved from $\mathrm{https} / / / \mathrm{www}$. busuu.com/en/p/start-learning?utm_medium $=\mathrm{cpc} \& u \mathrm{utm}_{-}$source=google\&utm_campaign=ROW _EN_Web_Brand_E\&utm_group=ROW_EN_Web_Brand_E\&utm_term $=$ busuu\&gclsrc $=$ aw.ds\&\&gclid $=\mathrm{Cj}$ wKCAjwlbr8BRA0EiwAnt4MTpPct4FbQVF1CbRNP-R2aECx-sErUtp3PDLrL6zOvNhfpuOc3NSLvxoC OOQQAvD_BwE

Stockwell, G. (2008). Investigating learner preparedness for and usage patterns of mobile learning. ReCALL: the Journal of EUROCALL, 20(3), 253. https://doi.org/10.1017/S0958344008000232

Thornton, P., \& Houser, C. (2005). Using mobile phones in English education in Japan. Journal of computer assisted learning, 21(3), 217-228. https://doi.org/10.1111/j.1365-2729.2005.00129.x

Valarmathi, K. E. (2011). Mobile assisted language learning. Journal of Technology for ELT, 2(2), 1-8.

Venkatesh, V., \& Davis, F. D. (1996). A model of the antecedents of perceived ease of use: Development and test. Decision sciences, 27(3), 451-481. https://doi.org/10.1111/j.1540-5915.1996.tb00860.x

Venkatesh, V., \& Davis, F. D. (2000). A theoretical extension of the technology acceptance model: Four

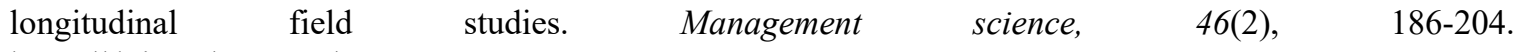
https://doi.org/10.1287/mnsc.46.2.186.11926

Vesselinov, R. O. U. M. E. N., \& Grego, J. O. H. N. (2016). The busuu efficacy study.

Yildiz, S. (2012). Use of iPad applications to introduce English as a foreign language to young Turkish learners. In CALICO Conference, University of Notre Dame, South Bend, IN. 


\section{Appendix}

\section{Survey}

We would like to thank you for taking part in the research "Perceptions of EFL Students Regarding the Use of the Application Busuu in Language Learning: Evaluating the Technology Acceptance Modal (TAM)." Your opinions will have a real impact on how the research will go on. This survey should take between 5-7 minutes of your time, and your responses are completely anonymous.

Thank you very much for your time.

Kindly response to the following statements by choosing the column that truly represents your opinion regarding the language application Busuu

First: Mobile assisted language learning (MALL)

\begin{tabular}{|c|c|c|c|}
\hline $\begin{array}{l}\text { To what extent do you agree or disagree with the following } \\
\text { statements regarding MALL }\end{array}$ & $\begin{array}{l}\text { Strongly } \\
\text { agree }\end{array}$ & Neutral Disagree & $\begin{array}{l}\text { Strongly } \\
\text { disagree }\end{array}$ \\
\hline Mobile phones can be an effective tool for EFL learners. & & & \\
\hline Portability is an important aspect of mobile phones. & & & \\
\hline Using mobile phones in language learning saves money. & & & \\
\hline Using mobile phones in language learning saves time. & & & \\
\hline $\begin{array}{l}5 \text { Mobile phones can provide EFL learners with an } \\
\text { interactive learning environment. }\end{array}$ & & & \\
\hline $\begin{array}{l}6 \text { Learning the language through a mobile application is } \\
\text { new to me. }\end{array}$ & & & \\
\hline
\end{tabular}

\section{Second: The Language Learning Application (BUSUU)}

Busuu as a language application in general

\begin{tabular}{|c|c|c|c|c|c|c|}
\hline \multicolumn{2}{|r|}{$\begin{array}{l}\text { To what extent do you agree or disagree with the following } \\
\text { statements about Busuu: }\end{array}$} & \multirow[t]{2}{*}{$\begin{array}{l}\text { Strongly } \\
\text { agree }\end{array}$} & \multirow[t]{2}{*}{ Agree } & \multirow[t]{2}{*}{ Neutral } & \multirow[t]{2}{*}{ Disagree } & \multirow[t]{2}{*}{$\begin{array}{l}\text { Strongly } \\
\text { disagree }\end{array}$} \\
\hline 7 & I use Busuu once to several times a day. & & & & & \\
\hline 9 & I spend from 5 to 10 minutes using Busuu & & & & & \\
\hline 10 & I spend more than 10 minutes using Busuu & & & & & \\
\hline 12 & $\begin{array}{l}\text { I think that the automated feedback in Busuu is excellent } \\
\text { (when your answer turns green if correct or red when you } \\
\text { make an error). }\end{array}$ & & & & & \\
\hline
\end{tabular}

\section{Third: Evaluating Busuu according to (TAM)}
A. The ease of use

\begin{tabular}{|c|c|c|c|c|c|}
\hline $\begin{array}{l}\text { To what extent do you agree or disagree with the following } \\
\text { statements regarding the ease of using Busuu: }\end{array}$ & $\begin{array}{l}\text { Strongly } \\
\text { agree }\end{array}$ & Agree & Neutral & Disagree & $\begin{array}{l}\text { Strongly } \\
\text { disagree }\end{array}$ \\
\hline Registering to Busuu was easy. & & & & & \\
\hline The using instructions in Busuu were clear. & & & & & \\
\hline I find Busuu simple in design and easy to navigate. & & & & & \\
\hline
\end{tabular}


18 I can manage my account and switch between lessons smoothly.

I think of Busuu as an accessible resource when I struggle with a particular topic in class.

20 I enjoyed learning the language using Busuu.

Third: Evaluating Busuu according to (TAM)

B. The usefulness

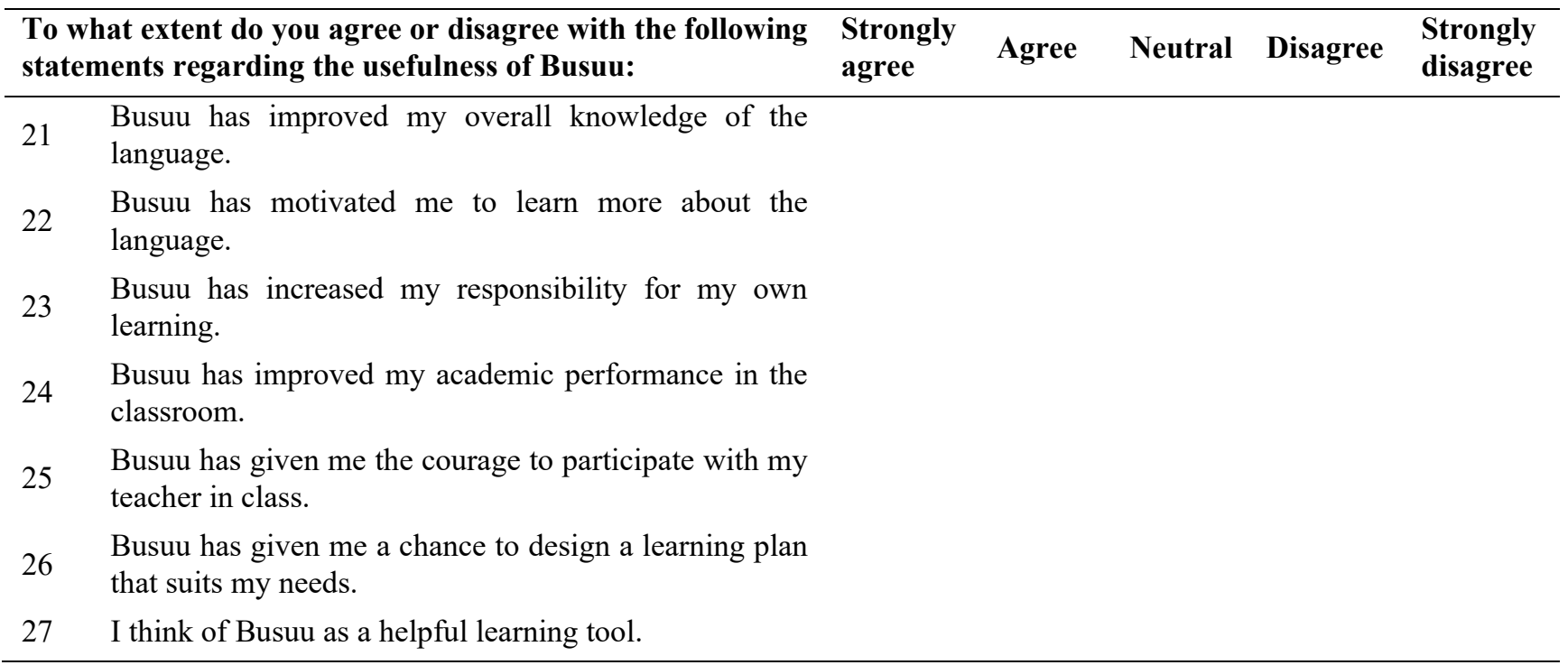

Fourth: EFL learners' Future expectations regarding the use of Busuu

\begin{tabular}{|c|c|c|c|c|c|}
\hline $\begin{array}{l}\text { To what extent do you agree or disagree with the following } \\
\text { statements regarding your expectations about Busuu: }\end{array}$ & \multirow[t]{2}{*}{$\begin{array}{l}\text { Strongly } \\
\text { agree }\end{array}$} & \multirow[t]{2}{*}{ Agree } & \multirow[t]{2}{*}{ Neutral } & \multirow[t]{2}{*}{ Disagree } & \multirow[t]{2}{*}{$\begin{array}{l}\text { Strongly } \\
\text { disagree }\end{array}$} \\
\hline Busuu was as I expected when I downloaded it. & & & & & \\
\hline $\begin{array}{l}\text { I want to see more from Busuu, so I downloaded the } \\
\text { premium membership. }\end{array}$ & & & & & \\
\hline $\begin{array}{l}\text { I have a plan of getting my MGH English language } \\
\text { certificate after finishing my current level. }\end{array}$ & & & & & \\
\hline $\begin{array}{l}\text { I consider using Busuu to learn other languages in the } \\
\text { future. }\end{array}$ & & & & & \\
\hline $\begin{array}{l}\text { Busuu has encouraged me to download other language } \\
\text { apps. }\end{array}$ & & & & & \\
\hline $\begin{array}{l}\text { Busuu has increased my interest in learning the } \\
\text { language. }\end{array}$ & & & & & \\
\hline
\end{tabular}

This survey was validated by:

\begin{tabular}{ll}
\hline Dr. Rasha Othman Abdulhalim Othman & Dr. Faizah Husain Mohammad, \\
English language department, Linguistics & Collage of education \\
Higher institute of technology, Egypt & Almajmaah University, AlMajmaah \\
\hline
\end{tabular}

\section{Copyrights}

Copyright for this article is retained by the author(s), with first publication rights granted to the journal.

This is an open-access article distributed under the terms and conditions of the Creative Commons Attribution license (http://creativecommons.org/licenses/by/4.0/). 